\title{
Budaya Lokal Pada Kampung Budaya Sindangbarang Bogor Dalam Ragam Teks Tulisan Mahasiswa Sebagai Bentuk Industri Kreatif Pembelajaran
}

\author{
Rina Rosdiana ${ }^{1}$ Siti Gomo Attas ${ }^{2}$ \\ Email: rinarosdiana0170@gmail.com ${ }^{1}, \underline{\text { tito.attas@gmail.com }}{ }^{2}$ \\ Received: 13 August 2021; Revised: 02 October 2021; Accepted: 28 December 2021 \\ DOI: http://dx.doi.org/10.37905/aksara.8.1.663-676.2022
}

\begin{abstract}
Abstrak
Penelitian ini mengkaji budaya lokal dalam ragam teks yang ditulis mahasiswa. Penelitian ini mengkaji pengertian, pemahaman, serta eksplorasi bentuk kelokalan budaya yang dipaparkan dalam beragam teks. Budaya dapat terlihat dalam sejumlah konsep, refresentasi prilaku manusia, dan dalam berbagai bentuk produk budaya. Metode penelitian yang digunakan adalah kualitatif deskriptif dengan teknik studi pustaka. Jenisjenis teks terdiri atas deskripsi, eksplanasi, eksposisi, dan prosedural. Keempat jenis tulisan tersebut merupakan objek kajian yang dilakukan secara acak. Hasil penelitian berupa ragam teks dengan mengacu pada data budaya di Kampung Budaya Sindangbarang kabupaten Bogor. Beragam teks dari 17 mahasiswa dibuat sebagai produk industri kreatif pembelajaran dalam perkuliahan. Pengembangan Keterampilan Menulis. Khusus analisis budaya lokal dipilih sepuluh teks, Pengembangan teks memuat budaya lokal dengan beragam genre teks. Teks deskripsi pada Kampung Budaya Sindangbarang. Permainan Egrang, Dampuh, dan Bakiak, dan permainan "Boy-boy-an" baik sebagai objek budaya atau filosofi nilai-nilai yang terkandung di dalamnya. Pada teks prosedur memuat Langkah-langkah melakukan teknik permainannya. Pada jenis teks eksposisi objek budaya itu dijabarkan sebagai sebuah konsep pemikiran yang argumentatif, seperti pelestarian Kampung Budaya. Sementara pada teks eksplanasi produk budaya tersebut lebih dilihat pada pemahaman konsep permainan

Kata kunci: budaya lokal, teks deskripsi, teks eksposisi, teks prosedural, industri kreatif,
\end{abstract}

\section{Pendahuluan}

Lingkungan masyarakat ataupun kondisi masyarakat dapat menjadi sarana, sumber, aktualisasi, dan stimulus terhadap suatu karya produktif. Karya produktif yang dekat dengan dunia bahasa dan siswa ataupun mahasiswa adalah produktivitas dalam menulis. Menuangkan gagasan dalam bentuk tulis yang berdasar pada pengalaman nyata di lingkungan sosial atau kebudayaan tertentu merupakan keuntungan dan nilai tersendiri dalam membangun atau menciptakan sebuah karya. Perubahan wujud dari pengalaman atau peristiwa yang terjadi pada lingkungan sekitar dan dikembngkan dalam bentuk media lain merupakan kegiatan yang besar manfaatnya. Produk yang dihasilkan untuk kegiatan tersebut adalah menulis suatu teks. Namun, situasi ini belumlah terrealisasi sesuai dengan harapan dalam pembelajaran atau pendidikan secara luas. Banyak peristiwa yang luput dari rekaman pendokumentasian. Hal tersebut tentulah diperlukan untuk 
pengembangan keilmuan, khususnya dalam pembelajaran bahasa yang dapat menghasilkan karya kreatif berupa tulisan dalam berbagaai bentuk teks.

Kemampuan siswa dalam berbahasa ini termasuk sastra di dalamnya, merupakan bagian dari kecakapan hidup. Resmini (2008:113) pun mengungkapkan mengenai keterampilan menulis ini sebagai berikut. Menulis merupakan suatu kegiatan yang tidak dapat dipisahkan dengan kehidupan manusia, karena manusia melakukan kegiatan berbahasa dalam kehidupannya melalui bahasa lisan dan bahasa tulis. Kemampuan menulis merupakan salah satu kemampuan bahasa yang semakin penting untuk dikuasai. Hal ini berkaitan erat dengan budaya industrial yang merupakan salah satu tuntutan pembangunan nasional pada masa yang akan datang. Budaya industrial ini menuntut anggota masyarakat memiliki wawasan, sikap, dan berbagai kemampuan yang sesuai dengan budaya tersebut. Salah satu kemampuan yang terpenting adalah kemampuan membaca dan menulis. Paltridge (2007) juga mengklaim bahwa siswa akan tetap memiliki masalah konvensi menulis jika guru tidak membawa bentuk dan pola penggunaan bahasa ini ke kesadaran mereka. Pendekatan genre disarankan untuk meningkatkan kesadaran siswa tentang cara yang berbeda dalam mengorganisasikan informasi dengan mendiskusikan ciri-ciri khas dari teks-teks bertujuan yang berbeda. Proses tersebut juga mendukung siswa secara sistemik untuk memperoleh kesadaran metalinguistik bahasa Inggris (Paltridge, 2001) dalam [1]; Meskipun orang berjuang dengan proses yang berhubungan dengan membaca, mereka pasti menghadapi kesulitan yang lebih besar dengan proses yang berhubungan dengan menulis, karena menulis lebih sulit daripada pemahaman membaca (Parodi, 2001; Cassany, 2009). [2]

Keterampilan menulis dipilih dalam penelitian ini berdasarkan pertimbangan bahwa keterampilan ini merupakan keterampilan yang aktif produktif. Produk yang dihasilkan mudah terlihat karena berupa hasil-hasil tulisan. Di samping itu, keterampilan menulis merupakan keterampilan yang dapat memperlihatkan kemampuan dalam mengungkapkan gagasan, pikiran, perasaan, dan terutama memperlihatkan kemampuan dalam menggunakan bahasa Indonesia secara baik dan benar. Ekspresi imajinatif dalam hasil sastra pun relatif mudah dilihat (mudah dibaca). "Konstruksi Bersama yang berhasil adalah praktik kelas paling kuat yang saat ini tersedia sejauh mempelajari genre tulisan yang bersangkutan" (hal. 73). Umumnya, konstruksi teks bersama yang dipimpin guru, sebagai cara untuk mendukung pengembangan menulis siswa, sangat dihargai dalam penelitian menulis (lihat Caplan \& Farling,2017) dalam [3]

Mahasiswa Program Studi Pendidikan Bahasa dan Sastra Indonesia merupakan calon guru bahasa yang diharapkan memiliki kemampuan melatihkan keterampilan atau kompetensi yang harus dikuasai siswa. Perlu pelatihan dan pengembangan konsep dan praktik pembelajaran yang merangsang pemahamana, aktivitas, dan produktivitas dalam menulis. Pada perkuliahan. Produk yang dihasilkan adalah beragam jenis teks yang dapat dimanfaaatkan sebagai salah satu referensi pembelajaran menulis bahasa Indonesia di sekolah sebagai bahan produk industri kreatif pembelajaran.

Berdasarkan konsep pengembangan pembelajaran bahasa dewasa ini sesuai dengan perkembangan keilmuan pada bidang pembelajaran Bahasa, pembelajaran diarahkan pada pengenalan, pemahaman, dan keterampilan memaknai dan memproduksi berbagai genre teks. Seperti yang diungkapkan Wiratno (2014) Genre sebagai jenis teks dapat digolongkan menjadi genre faktual dan genre fiksi atau rekaan...Genre faktual adalah jenis teks yang dibuat berdasarkan kejadian-kejadian, peristiwa atau keadaan nyata 
yang berada di sekitar lingkungan hidup, sedangkan .Genre fiksi adalah jenis teks yang berdasarkan imajinasi, bukan pada kegiatan yang sesungguhnya.

Dalam pembelajaran bahasa yang berbasiskan teks, bahasa Indonesia diajarkan bukan sekadar sebagai pengetahuan bahasa, melainkan sebagai teks yang berfungsi untuk menjadi sumber aktualisasi diri penggunanya pada konteks sosial-budaya akademis. Teks dipandang sebagai satuan bahasa yang bermakna secara kontekstual. mengajar menulis dari perspektif yang lebih konsisten dengan kenyataan. Perspektif ini memandang menulis sebagai praktik literasi, bukan hanya sebagai resep di mana formula tentang bagaimana menggunakan konjungsi dan penghubung atau elemen kohesif lainnya diajarkan. Untuk mencapai tujuan ini, genre teks dipilih sebagai objek pengajaran. Karena tidak mungkin membangun teks atau membangun makna di dalamnya tanpa struktur gramatikal, kami juga menganggap bahwa tata bahasa memainkan peran penting dalam proposal semacam ini. [4]

Mahsun (2014:vii) mengungkapkan lebih jauh bahwa pembelajaran bahasa Indonesia berbasis teks dilaksanakan dengan menerapkan prinsip bahwa (1) bahasa hendaknya dipandang sebagai teks, bukan semata-mata kumpulan kata-kata atau kaidahkaidah kebahasaan, (2) penggunaan bahasa merupakan proses pemilihan bentuk-bentuk kebahasaan untuk mengungkapkan makna, (3) bahasa bersifat fungsional, yaitu penggunaan bahasa yang tidak pernah dapat dilepaskan dari konteks karena dalam bentuk bahasa yang digunakan itu tercermin ide, sikap, nilai, dan ideologi penggunanya, dan (4) bahasa merupakan sarana pembentukan kemampuan berpikir manusia. Setiap teks memiliki struktur tersendiri. Dalam struktur teks tersebut tercermin kemampuan berpikir. Penguasaan terhadap berbagai jenis struktur teks memudahkan siswa menggunakannya dalam kehidupan sosialnya di samping kemampuan berpikir siswa pun berkembang. Dengan demikian, jelaslah bahwa teks merupakan sarana dalam membentuk struktur kognitif para siswa. Dan guru seyogianya melatihkan berbagai jenis teks tersebut.

Bila dikaitkan dengan konteks lokasi yaitu sekolah menengah di Bogor, teks yang disusun dan dikembangkan berdasar pada topik-topik berbudaya sunda. Konten materi baik dapat dikembangkan dari lingkungan Bogor. Banyak teks yang terdapat pada bukubuku teks pelajaran, namun yang berbudaya lokal sunda (Bogor) masih sedikit, padahal menumbuhkan kecintaan pada budaya lokal sangat diharapkan pemerintahan Kota/Kabupaten Bogor. Hal ini dibuktikan dengan gerakan "Rebo Nyunda". Materi terkait beragam jenis teks diharapkan bisa dikembangkan guru (calon guru) sebagai upaya penanaman rasa cinta pada budaya bangsa. Selain itu, adanya Kampung Budaya Sindangbarang dapat menjadi sumber pengembangan kreativitas mahasiswa dalam menulis. Objek-objek wisata di Kampung Budaya Sindangbarang dapat menjadi sumber penulisan.

Berdasarkan permasalahan di atas, maka masalah dalam penelitian ini yakni, pengembangan unsur-unsur budaya lokal dalam teks faktual dalam teks mahasiswa Program Studi Pendidikan Bahasa dan Sastra Indonesia FKIP Unpak dan Teks faktual yang menjadi kajian dalam penelitian ini adalah (i)Teks deskripsi, (2) Teks eksposisi, (iii) Teks eksplanasi, dan (iv) Teks prosedur kompleks. 


\section{Kajian Teoretis}

\subsection{Pengertian Teks}

Teks merupakan segenap rangkaian kegiatan seseorang dalam mengungkapkan pikirannya melalui bahasa tulis untuk dibaca dan dimengerti oleh orang lain. Teks merupakan suatu kepandaian yang amat berguna bagi setiap orang. Fakta menunjukkan bahwa manusia hidup dalam dunia kata-kata. Apabila kata-kata dirangkai untuk mengkomunikasikan gagasan atau makna, sebenarnya kita telah menciptakan teks. pengekspresikan gagasan secara lisan (berbicara) atau secara tulis (menulis) adalah menciptakan teks. Menyimak atau membaca, pada dasarnya menginterpretasikan makna teks. Oleh karena itu, teks dapat berupa ujaran (lisan) atau tulisan yang bermakna yang memiliki berfungsi untuk mengekspresikan gagasan.

Untuk memahami lebih dalam tentang teks, berikut ini disajikan berapa pengertian teks menurut para ahli.

Teks merupakan jalan menuju pemahaman tentang bahasa. Itu sebabnya, teks merupakan bahasa yang berfungsi atau bahasa yang sedang melaksanakan tugas tertentu dalam konteks situasi. Teks ialah pemahaman awal seseoarng tentang bahasa yang fungsinya digunakan berdasarkan situasi (Halliday dalam Mahsur, 2014: 1); Christie dan Misson (dalam Emilia, 2012: 4), teks didefinisikan sebagai kata-kata atau kalimat yang ditenun untuk menciptakan satu kesatuan yang utuh; Priyatni (2014: 37), teks merupakan bahasa sebagai sarana untuk mengekspresikan gagasan yang biasanya direalisasikan dalam bentuk teks. Mempelajari genre berarti belajar bagaimana "berpartisipasi dalam aksi komunitas" (Miller 1984, P. 165); Melissourgou (2017)

Berdasarkan pendapat tersebut teks disimpulkan sebagai sebuah rangkaian kata-kata yang utuh, baik strukturnya maupun kebahasaannya Kata tersebut akan menjadi sebuah paragraf yang terdapat kalimat utama dan penjelas sehingga menghasilkan rangkaian kata yang yang dapat dibaca orang lain.

\subsection{Budaya atau Kebudayaan}

Kebudayaan adalah abstraksi, maka perlu untuk tidak mengacaukan pengertian kebudayaan dan masyarakat. Suatu masyarakat mengacu pada suatu kelompok manusia yang lebih berinteraksi satu sama lain daripada individu-individu lain yang bekerja sama satu sama lain untuk mencapai tujuan-tujuan tertentu. Suatu kebudayaan mengacu pada berbagai cara hidup kelompok seperti itu (Suparlan, 1984:80). Setiap kebudayaan merupakan perangkat teknik untuk menyesuaikan diri dengan lingkungan yang dihadapi dengan orang lain. Kebudayaan menciptakan kebutuhan dan alat untuk memenuhi kebutuhan tersebut. Dalam setiap kelompok terdapat dorongan kebutuhan yang ditentukan oleh kebudayaan (Suparlan, 1984:84).

Suatu kebudayaan diperoleh melalui proses belajar oleh individu-individu sebagai hasil interaksi anggota-anggota kelompok satu sama lain, sehingga kebudayaan juga dapat bersifat dimiliki bersama. Kebudayaan sebagai warisan sosial dalam hal ini dibedakan (kontraks) dengan warisan organik. Ini merupakan salah satu faktor penting yang menyebabkan kita bisa hidup bersama dalam suatu masyarakat yang terorganisasi, yang memberikan kepada kita cara pemecahan masalah yang siap pakai, yang membantu 
kita melakukan prediksi mengenai kelakuan orang lain, dan menyebabkan orang lain bisa mengetahui apa yang bisa diharapkan dari kita (Suparlan, 1984:83).

Kebudayaan terdiri atas berbagai pola, bertingkah laku, pikiran, perasaan, dan reaksi yang diperoleh dan terutama diturunkan oleh simbol-simbol yang menyusun pencapaiannya secara tersendiri dari kelompok-kelompok manusia, termasuk perwujudan benda-benda materi. Pusat esensi kebudayaan terdiri atas tradisi cita-cita, dan terutama keterikatan terhadap nila-nilai. Ketentuan-ketentuan ahli kebudayaan itu sudah bersifat universal dan diterima oleh pendapat umum meskipun dalam praktik, arti kebudayaan menurut pendapat umum ialah sesuatu yang berharga atau baik (Bakker dalam Sulaeman, 1984:21).

Para ahli sudah banyak menyelidiki berbagai kebudayaan. Dari hasil penyelidikan tersebut timbul dua pemikiran tentang munculnya suatu kebudayaan atau peradaban. Anggapan pertama bahwa adanya hukum pemikiran atau perbuatan manusia yang disebabkan oleh tindakan besar yang menuju kepada perbuatan yang sama dan penyebabnya sama. Kedua, adanya anggapan bahwa tingkat kebudayaan atau peradaban muncul sebagai taraf perkembangan dan hasil evaluasi masing-masing sejarah.

Dari banyaknya pengertian yang telah dikemukakan oleh berbagai para pendapat, dapat disimpulkan bahwa budaya atau kebudayaan merupakan suatu tingkah laku, kebiasaan, dan peraturan yang wajib dilakukan serta dilaksanakan oleh setiap individu maupun masyarakat dalam suatu daerah. Kebiasaan itu sudah melakat dalam diri setiap orang, sehingga kebiasaan-kebiasaan tersebut diajarkan secara turun temurun dan sulit untuk dilupakan.

Koentjaraningrat (1980:15) menungkapkan bahwa wujud kebudaayaan pada dasarnya meliputi tiga hal, pertama, wujud kebudayaan sebagai suatu kompleks dari ideide, gagasan, nilai-nilai, norma-norma, peraturan dan sebagainya. Hal ini bisa dimasukkan ke dalam bagian nilai budaya. Kedua, wujud kebudayaan sebagai suatu kompleks aktivitas kelakuan berpola dari manusia dalam masyarakat yang kemudian dikenal dewngan sebutan sistem sosial. Dan ketiga, adalah wujud kebudayaan sebagai benda-benda hasil karya manusia atau tepatnya apa yang dikenal dengan sebutan kebudayaan fisik. Dalam kebudayaan tersebut tercermin kembali nilai-nilai berkaitan dengan peran anggota masyarakat.

Koentjaraningrat (1985:28) memaparkan bahwa semua nilai budaya itu sebenarnya mengenai lima masalah pokok dalam kehidupan manusia, yaitu (1) hakikat dari hidup manusia, 2) hakikat dari karya manusia, 3) hakikat dari kedudukan manusia dalam ruang dan waktu, 4) hakikat dari hubungan manusia dengan alam sekitar, dan 5) hakikat dari hubungan manusia dengan sesamanya. Nilai-nilai budaya menjadi masyarakat menjadi landasan perilaku masyarakat yang kehadirannya masih dpat diamati dan dipahami. Hal tersebut misalnya terwujud dalam bentuk-bentuk doa, upacara-upacara keagamaan, cerita-cerita rakyat, dan adat istiadat (Baried dkk, 1985:2) dalam Depdikbud (1994: 2).

Kebudayaan adalah hasil dari cipta, karsa, dan rasa manusia yang diwujudkan dalam tiga gejala, yakni

1) Ide, konsep, gagasan, nilai, norma, peraturan dan lain-lain;

2) Kegiatan, yakni tindakan berpola dari manusia dalam masyarakat; dan

3) Benda hasil karya manusia. 
Keseluruhan dari tindakan manusia yang berpola teramat banyak jumlahnya, yang dapat dikategorikan dalam dua unsur, yakni (a) unsur yang bersifat universal dan (b) unsur yang bersifat khusus. Unsur universal, artinya kebudayaan yang berlaku umum bagi setiap manusia di muka bumi ini. Sedangkan unsur khusus, artinya dalam kebudayaan yang sifatnya universal tersebut ada unsur-unsur yang khusus. Khickhom membagi tujuh kategori kebudayaan universal, yakni (a) bahasa, (b) sistem pengetahuan, (c) organisasi sosial, (d) sistem peralatan dan teknologi, (e) sistem mata pencaharian, (f) sistem religi, dan $(\mathrm{g})$ kesenian.

\subsection{Kampung Budaya Sindangbarang}

Kampung Budaya Sindang Barang adalah suatu kampung adat Sunda yang terletak di Desa Pasir Eurih Kecamatan Taman Sari Kabupaten Bogor. Menurut sejarahnya Kampung Sindang Barang sudah ada sejak abad ke XII dan terpapar dalam Babad Pajajaran dan tertulis juga dalam pantun Bogor. Kebudayaan Sunda yang masih kental tercermin dalam perilaku kehidupan masyarakatnya sehari-hari terutama direfleksikan dalam pelaksanaan acara Serentaun yang rutin dilaksanakan di Kampung Sindang Barang. Menurut penjelasan Prasetyo (2011) Kampung Budaya Sindang Barang adalah salah satu kampung adat dari 20 kampung adat yang ada di Jawa Barat. Kampung Budaya Sindang Barang adalah salah satu komunitas yang hingga kini mempertahankan aspek kebudayaan lokal kerajaan Pajajaran, dimana terdapat 78 lokasi situs sejarah Pakuan Sindangbarang, upacara tradisional (upacara adat Serentaun, upacara adat Neteupken, upacara adat Pabeasan, dan berbagai upacara adat lainnya), dan berbagai kesenian tradisional Sunda. Salah satu ritual tradisi Sunda yang menjadi ciri khas Kampung Budaya Sindang Barang adalah Serentaun. Serentaun merupakan suatu bentuk penjelmaan rasa syukur warga atas rezeki hasil panen mereka.

Terdapat pula bangunan yang menyediakan berbagai peralatan musik, tari, hingga permainan tradisional. Disini pengunjung bisa belajar menari atau bermain gamelan, angklung, dan alat musik tradisional yang dipandu langsung oleh gurunya. Pada waktuwaktu khusus juga diadakan pementasan seni seperti Jaipongan yang siap menghibur pengunjung. Selain kegiatan seni, ada juga praktek kegiatan kebudayaan warga seperti Numbuk Padi, Nandur, hingga memandikan Kerbau. Tak ketinggalan, pengunjung yang datang rombongan juga bisa mengikuti permainan tradisional. Alat dan perlengkapan lain sudah disiapkan termasuk pemandu yang akan mengajarkan dan menjelaskan cara bermainnya. Kegiatan atraktif ini biasanya dilakukan jika pengunjung memesan paket wisata khusus. (https://travelspromo.com/htm-wisata/kampung-budaya-sindang-barang/)

\section{Metode Penelitian}

\subsection{Jenis Metode penelitian}

Sesuai dengan tujuan penelitian, metode yang digunakan dalam penelitian ini adalah metode kualitatif yang mengacu kepada pandangan naturalistik berdasarkan pertimbangan bahwa penelitian ini bermaksud meneliti dan mengkaji secara mendalam peristiwa atau kejadian dalam seting penelitian yang alami, penelitian yang memotret apa adanya berdasarkan peristiwa yang terjadi. Moleong, mengungkapkan bahwa penelitian kualitatif merupakan penelitian yang menggunakan latar alamiah, dengan maksud menafsirkan penomena yang terjadi dan dilakukan dengan jalan melibatkan berbagai 
metode penelitian yang ada. Metode yang biasanya dimanfaatkan adalah wawancara, pengamatan, dan pemanfaatan dokumen.

Metode penelitian ini dipilih dengan alasan untuk menghasilkan data atau keadaan mengenai objek yang diteliti dengan benar dan didukung data atau fakta empiris. Pemilihan metode kualitatif ini bertujuan untuk mengungkap berbagai informasi kualitatif atau menghasilkan data kualitatif. Bogdan dan Taylor dalam Moleong (2005: :4) dalam mengungkapkan bahwa informasi kualitatif diperoleh dengan pendeskripsian yang teliti dan penuh nuansa untuk menggambarkan secara cermat sifat-sifat suatu hal (individu, organisasi, atau kelompok), keadaan, gejala, atau fenomena yang lebih berharga daripada sekadar pernyataan jumlah ataupun frekuensi dalam bentuk angkaangka dan tidak terbatas pada pengumpulan data melainkan meliputi analisis dan interpretasi data tersebut sebagai bagian dari sesuatu yang utuh.

Dalam penelitian ini, peneliti mencatat dan merekam semua informasi yang tampak, informasi yang digali melalui dokumentasi. Tujuannya untuk dapat mendeskripsikan data kemampuan mahasiswa dalam mengembangkan gagasan pada karangan eksposisi dalam kemasan artikel populer.

\subsection{Data dan Sumber Data}

Mendapatkan data empirik merupakan hal utama dalam penelitian kualitatif. Data bisa diperoleh dari berbagai sumber dengan macam-macam teknik pengumpulan data. Dalam penelitian ini data diperoleh dengan studi dokumentasi dan tes kemampuan menulis.

Data dalam penelitian ini adalah berbagai jenis teks faktual, yakni; 1) Teks Deskripsi, 2) Teks Eksplanasi, 3) teks Eksposisi, dan 4), Teks Prosedur Kompleks. Sumber data dari ragam teks yang dipilih oleh mahasiswa mengenai objek budaya di kampung Budaya Sindangbarang Bogor.

\section{Hasil dan Pembahasan}

Pengembangan tulisan mahasiswa dimulai dengan konsep teksnya. Secara konsep disajikan mulai dari pengertiam struktur teks, dan contoh teksnya. Berikut ilustrasinya.

\section{a. Teks Deskripsi}

\section{1) Pengertian Teks Deskripsi}

Deskripsi adalah tulisan yang bersifat menyebutkan karakteristik-karakteristik suatu objek secara keseluruhan, jelas, dan sistematis. (Tompkins dalam Zainurrahman, 2013:45) menyebutkan bahwa tulisan deskripsi adalah tulisan yang seolah-olah "melukis sebuah gambar dengan menggunakan kata-kata." Dengan kata lain, tulisan deskripsi digunakan oleh penulis untuk menggambarkan sebuah keadaan atau situasi, karakter objek secara komprehensif, dengan mengandalkan kosakata.

"Menggambarkan" adalah kata kunci dari pengertan tulisan deskripsi, sama dengan dasar itulah dapat dipahami bahwa fungsi sosial dari tulisan deskripsi adalah memberikan gambaran kepada pembaca. Dalam menulis teks deskripsi, penulis berusaha semaksimal mungkin agar pembaca seolah-olah dapat melihat, mengalami, merasakan, apa yang sedang dideskripsikan (Zainurrahman, 2013:45).

Dari pendapat ahli di atas dapat dijelaskan bahwa teks deskripsi adalah teks yang mengambarkan suatu keadaan dari sebuah objek yang menjelaskan karakteristik bentuk, atau suasana tertentu yang disampaikan dalam sebuah teks yang membawa pembacanya seolah-olah berada dalam situasi tersebut. 
Berdasarkan definisi di atas, teks deskripsi merupakan rangkaian tutur yang memaparkan atau melukiskan sesuatu biasanya berdasarkan pengalaman serta pengetahuan yang dimiliki oleh penulis itu sendiri. Teks deskripsi ini biasanya memaparkan suatu objek dengan imajinatif sehingga objek dapat tergambar dengan jelas.

\section{2) Struktur Teks Deskripsi}

Berdasarkan kurikulum 2013 buku guru kelas VII dan buku teks dalam pembelajaran bahasa indonesia kurikulum 2013 (Mahsun, 2014:29) menjelaskan bahwa struktur teks deskripsi itu mencakup deskripsi umum dan deskripsi bagian/uraian bagianbagian. Dalam deskripsi umum penulis menyatakan sesuatu yang akan dideskripsikannya. Pada deskripsi bagian penulis mendeskripsikan beberapa aspek dari topik yang diceritakan. Berikut contoh produk tulisan mahasiswa mengenai teks deskripsi.

\section{Kampung Budaya Sindang Barang}

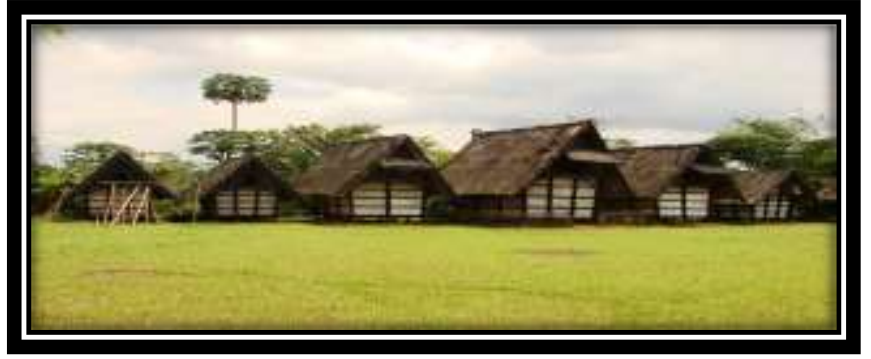

Gb 1. Kampus Budaya Sindangbarang

Kampung budaya merupakan lokasi khusus yang masih memiliki sejarah masa lalu yang mempertahankan tradisi yang ada. Masih ditemukannya jejak sejarah dan pola hidup lama yang bisa dipertahankan. Kampung secara umum berarti sebuah kumpulan komunitas terdiri dari berbagai masyarakat beragam etnis atau etnis tertentu yang berdiam dalam satu wilayah dan hidup secara berkelompok dengan pola hidup sederhana memiliki aturan yang arif dan bijak dan dipraktekan dalam kehidupan seharihari.Sedangkan Budaya merupakan kegiatan turun-temurun yang di wariskan dari nenek-moyang yang harus di jaga kelestariannya hingga sekarang.Di bogor terdapat kampung budaya bernama kampung budaya Sindang Barang

Kampung budaya Sindang Barang terletak di desa pasir eurih kec. tamansari, kab. Bogor, Jawa Barat, Indonesia. Jaraknya kurang lebih sekitar $5 \mathrm{~km}$ dari kota Bogor.Kampung Budaya Sindang Barang merupakan sebuah Kampung Tertua di Wilayah kota dan kabupaten Bogor, berdasarkan sumber dari naskah Pantun Bogor.Kampung budaya Sindang Barang ada semenjak jaman Kerajaan Sunda. Kampung Budaya Sindang Barang juga merupakan bagian dari Kampung adat Sindang Barang.Awalnya pada zaman dahulu kala setiap 8 tahun sekali masyarakat mengirim upeti sesuai apa yang mereka tanam dan ternakan pada jaman itu dan disinilah dahulunya terdapat sebuah Kerajaan yang bernama Sindangbarang.Menurut dari cerita rakyat, dahulunya disini menjadi tempat dilatihnya para satria-satria kerajaan. Disini juga awal mula dari kebudayaan Sunda Bogor yang bertahan sampai saat ini yang diwujudkan dalam Upacara Adat Seren Taun. 
Situs purbakala yang kedua adalah situs Batu Kursi Malas, dinamakan demikian karena bentuk batu memanjang seperti tempat beristiahat untuk bermalas-malasan.Batu kursi malas ini ditemukan di pekarangan rumah ketika sedang membangun rumah yang punya rumah menemukan batu ini dan menaruhnya dipekarangan rumah.

Dalam penelitian ini dihasilkan beberapa tipikal tulisan yang berkenaan dengan objek atau peristiwa budaya sebagai sebuah produk pada mulanya. Penamaan yang melatari tulisan sekaligus yang dijadikan judul tulisan adalah esensi sekaligus substansi maksud.

Teks disajikan dengan beragam teks seperti yang diungkap tipe-tipe teks. Types of text can be divided into 12 categories, namely recount, report, discussion, explanation, exposition analytical, exposition hortatory, news item, spoof, narrative, procedure, description, and review (Herman, 2014; Pardede \& Herman, 2020; Rajagukguk, Herman, \& Sihombing, 2020; Sinaga, Herman, \& Hutauruk, 2020) dalam Herman [5] Dari tujuh belas tulisan yang terkumpul dengan objek atau peristiwa budaya yang jadi acuannya dapat kami klasifikasikan sebagai berikut. (i) Teks Laporan Observasi, (ii) Teks Deskripsi, (iii) Teks Prosedur, (iv) Teks Rekon, (v) Teks Eksplanasi, (vi) Teks Eksposisi, (vii) Teks Diskusi, (viii) Teks Negosiasi, (ix) Teks Naratif. Teks

Pada teks deskripsi, tulisan tersebut ditelaah berdasarkan pemahaman yang dikuasai serta penggambarannya. Sebuah produk ditandai dengan penamaan termasuk kegiatan yang menyertainya. Objek budaya tersebut ditandai sebagai penamaan atau permainan, seperti Egrang, Bakiak, dan Dampuh. Salah satu contoh permainan adalah Egrang sebagai produk budaya. Dalam perspektif mahasiswa Egrang didefiniskan dengan Salah satu permainan tradisional Indonesia. Egrang dibuat dengan sangat sederhana dengan menggunakan dua batang bambu yang panjangnya kurang lebih 2,5 meter. Kemudian sekitar $50 \mathrm{~cm}$ dari alas bambu tersebut; Permainan lainnya, yang mengajarkan benda sebagai fasilitas permainan adalah Boy-boyan.Alat yang dibutuhkan untukpermainan ini adalah pecahan genteng dan bola plastik atau bola kasti. Permainan boy-boyan biasanya dimainkan oleh 5-10 orang. Pemain harus menjatuhkan susunan genteng dengan menggunakan bola.Dalam hubungannya dengan objek budaya, penamaan menyertakan peralatan budaya sebagai produk yang masyarakat ciptakan atau miliki. Objek budaya adalah penamaan sekaligus juga adalah peralatan budaya tempat kreativitas masyarakat ciptakan atau mainkan. Sebuah permainan yang bertolak dari alam dan ada di sekitar kehidupan di sekitar mereka.

Pada teks eksposisi, Cara meyakinkan pada teks ekpsosisi adalah dengan tetap berangkat pada alasan yang juga faktual. Berikut adalah kutipannya tentang sebuah arca yang tepatnya bernama Arca Domas.

Di Kampung Budaya Sindangbarang ini terdapat 8 jenis kesenian Sunda yang sudah direvitalisasi dan dilesarikan oleh para penduduknya. Di sini juga terdapat berbagai situs purbakala peninggalan Kerajaan Padjadjaran yang berupa bukitbukit berundak. Di Sindang Barang ini padasetiap tahun diselenggarakan sebuah upacara ungkapan rasasykur masyarakat desa ini....

Sementara itu, pada teks tentang Jaipong, argumentasi sekaligus alasan dan harapan dikemukakan "Seharusnya dalam hal seni tari, semua harus ikut serta melestarikan kebudayaan ini karena demi masa depan kelak, pemerintah pun ikut ambil serta dalam 
pelaksanaan melestarikan kesenian khas ke depannya dalam menjaga dan melestarikan tarian ini" Sementara itu, Jaipong, misalnya, juga bukan sekadar nama akan tarian,melainkan.

Sebagai kebudayaan yang dimiliki oleh negara Indonesia dengan setiap gerak yang diperagakannya oleh penari mempunyai makna. Kami sangat peduli dan miris melihat budaya modern yang kebarat-baratan karena melupakan jati diri sebagai penerus dan pewaris kebudayaan negeri ini

Kemudian, pada teks prosedur memaparkan langkah-langkah. Yang cocok dengan teks ini adalah topik yang berkaitan dengan proses atau sesuatu dilakukan. Teks ini lebih menekankan struktur teks dan kebahasaan adalah pada cara kerja atau langkah kerja. Dalam hubungannya dengan objek budaya, sebuah permainan atau cara memainkannya dapat dijelaskan melalui teks ini. Langkah-langkah memainkan Egrang, misalnya.

"Pertama, bambu atau kayu sebesar lengan dipotong membujur panjang sekitardua atau tiga meter dan disesuaikan dengan ukuran tinggi badan si pemakai. Jika si pemakai memiliki tubuh yang tinggimaka harus panjang dan tinggi pula bambu yang digunakan.

Kedua, pilihlah bambu yang agak besar tetapi cukup untuk digenggam oleh telapak tangan. Biasanya bambu yang digunakan yaitu bambu tali. Orang Sunda biasanya menyebutnya dengan awi tali, bambu wulung atau sejenisnya. Jangan menggunakan bambu betung atau gombang karena ukuran bambu ini lumayan besar."

Dua teks prosedur menjelaskan sebuah nama permainan. Dalam teks tersebut berdasarkan 7 unsur kebudayaan, dua nama benda yang menyertai permainan tersebut yanitu Egrang dan Bakiak adalah peralatan hidup yang difungsikan lebih jauh dalam kehidupankehidupan yang berkaitan dengan kebersamaan. Filosofi yang menyertai langkah-langkah tersebutadalah persyaratan, bagaimana aturan main, dan untuk alasan apa sesuatu itu dimainkan. Dengan kata lain, permainan adalah juga pesan-pesan kehidupan yang diungkapkan secara tersirat.

Bambu pada permainan Egrang ataupun kayu pada permainan Bakiak berkaitan dengan hal-ihwal konteks sosial-budaya, ada dalam lingkup sehari-hari dan sepenuhnya dikerjakan dengan tangan-tangan manusia. Ada keterampilan, usaha mencari, serta bagaimana komunikasi dilakukan di antara anggota pemain.

Sementara itu, diungkap juga dalam Suhendra, dkk, (2016) mahasiswa melihat Bakiak, bukan sekadar bambu dan permainan kayu yang ditekan atau diinjak, diyakini bahwa bermain Bakiak adalah konsep akan harapan dan tujuan ideal. Ini mengingatkan betapa tipisnya batas-batas tulisan deskripsi, eksplanasi, sekalaigus eksposisi.Permainan yang kini mulai terkikis peradaban zaman yang kian modern dengan berbagai kecanggihan teknologi. Permainan yang berangsur-angsur menghilang, dilestarikan kembali melalui program Kampung Budaya. Bakiak adalah permainan tradisional yang mengajarkan nilai kerja sama dan kepemimpinan. Sementara itu, di mata mahasiswa Dampuh juga bukan sekadar permainan antarbatu, meliankan Dampuh adalah permainan tradisional yang mengajarkan nilai kegigihan. Sama seperti Dampuh, permainan Boyboyan adalah juga Boy-boyan adalah permainan tradisional yang mengajarkan kegigihan. 


\subsection{Unsur Kebudayaan}

Yang tecermin di balik Dampuh, Egrang, Bakiak, dan Boy-boyan adalah sebatas benda, Jaipong adalah gerak, Arca Domas adalah situs. Itu adalah pemandangan sepintas yang kasat mata di balik aneka permainan atau peristiwa budaya yang jadi bahan kajian dalam penelitian ini. Sebagai bagian dari aktivitas kehidupan manusia Sunda khusunya, permainan dan filosofi yang berkaitan dengan budaya lokal bukanlah sebatas nama yang tidak memiliki arti sama sekali, melainkan, berdasarkan telaah dan pemaparan tulisan, kelolakan adalah bagian integral dari kepemilikan sah masyarakat. Ini akan berarti, kelokalan adalah cermin kehidupan sosial-budaya masyakarat. Kelokalan juga adalah warisan tak ternilai dari pola hidup masyarakat di tingkat konsep, permainan, hingga filosfi. (Suhendra, dkk, 2016)

Bahwa bermain bukan sekadar melakukan permainan yang dijalani, melainkan adalah juga meresapi makna yang terkandung di balik permainan itu. Kerja sama antarmanusia, misalnya, dengan tegas menjelaskan relasi sosial yang hangat, gigih, dan hidup secara bergotong royong dan harmonis. Di sisi lain, permainan merefleksikan hidup yang tidak pantang menyerah dalam mengejar harapan dan kemauan. Ini sekaligus mengajarkan pentingnya hidup dengan kinerja yang baik, pantang menyerah jadi hal yang tidak terpisahkan dalam aktivitas kita di mana pun.

\section{Industri Kreatif}

DIKN sebagai kebijakan industry kreatif. Seperti banyak kebijakan industri kreatif di seluruh dunia, DIKN mengacu pada definisi industri kreatif dari Departemen Budaya Media dan Olahraga Inggris (DCMS, 1998). Mendefinisikan industri kreatif sebagai "Industri yang berasal dari kreativitas, keterampilan dan bakat individu dan yang memiliki potensi kekayaan dan penciptaan lapangan kerja melalui generasi dan eksploitasi kekayaan intelektual," mengidentifikasi 13 sub-sektor. Sebaliknya, DIKN mengidentifikasi 14 sub-sektor, membaginya menjadi tiga kategori: Multimedia Kreatif, Seni Budaya Kreatif, dan Warisan Budaya Kreatif (lihat Tabel 1). Secara khusus DIKN secara eksplisit menekankan penekanan yang diberikan kepada media digital, yang telah menjadi fokus instansi pemerintah, khususnya MDEC. [6]

Tabel 1 Klasifikasi DIKN Industri Kreatif

\begin{tabular}{|c|c|c|}
\hline $\begin{array}{lr}\text { Industri } & \text { Kreatif } \\
\text { Multimedia } & \\
\text { (Kreatif } & \text { Multimedia } \\
\text { Industri) } & \end{array}$ & $\begin{array}{lll}\begin{array}{l}\text { Industri } \\
\text { Budaya }\end{array} & \text { Kreatif } & \text { Seni } \\
\text { (kreatif } & \text { Seni } & \text { Budaya } \\
\text { Industri) } & & \end{array}$ & $\begin{array}{ll}\text { Industri Kreatif } & \text { Budaya } \\
\text { (Warisan } & \text { budaya } \\
\text { Industri Kreatif) }\end{array}$ \\
\hline $\begin{array}{l}\text { Penerbit Film dan } \\
\text { (Film dan TV) }\end{array}$ & Kraf (kerajinan) & Museum \\
\hline Periklanan & Seni Visual & Arsip \\
\hline Seni Reka (Desain) & Seni Musik & Pemulihan (Restorasi) \\
\hline Animasi dan konten digital & $\begin{array}{l}\text { Seni pertunjukan (Pentas } \\
\text { Seni) } \\
\text { Penulisan Kreatif } \\
\text { Fesyen dan Tekstil (Mode } \\
\text { dan Tekstil }\end{array}$ & Pemeliharaan (Kelestarian) \\
\hline
\end{tabular}


Produk kreatif penelitian ini adalah buku ajar beragam teks denga isi budaya . Jika dilihat dari tabel di atas merupakan industry kreatif seni Budaya. Didalamnya memuat 17 tulisan beragam teks faktual berbasi budaya di Kampung Budaya Bogor. Visualisasi tampak pada cover buku berikut.

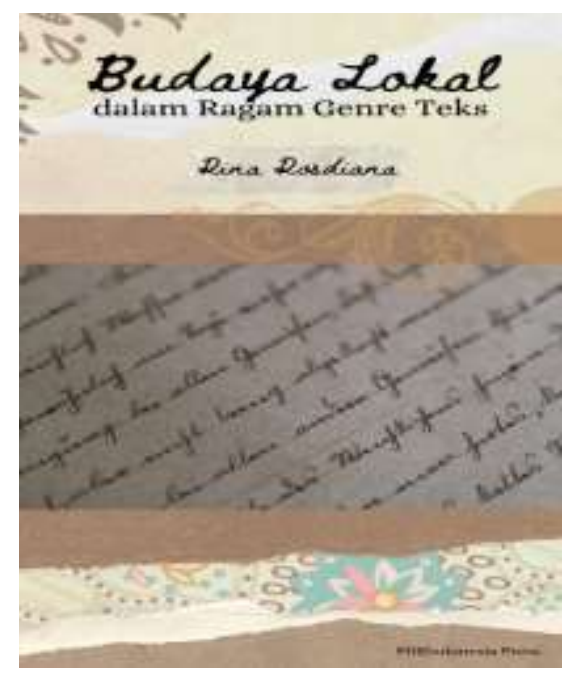

\section{Simpulan}

Setelah melakukan kajian dan analisis data dapat ditarik beberapa simpulan, yakni:

1. Perubahan paradigma pembelajaran bahasa Indonesia yang berorientasi pada pendekatan teks (berbasis teks), baik di sekolah dasar, menengah, maupun perguruan tinggi berdampak terhadap pengembangan materi pelajaran bahasa Indonesia itu sendiri. Bahasa Indonesia dipandang dalam bentuk teks dan sarana kemampuan berpikir manusia bukan kumpulan kaidah-kaidah kebahasaan. Sebagai sarana berpikir, teks dapat mengungkapkan berbagai topik; salah satunya unsur budaya yang ada pada suatu wilayah tertentu (budaya lokal) dalam hal ini budaya Sunda

2. Teks sebagai wadah penanaman nilai-nilai budaya memiliki karakteristik dan struktur teks berbeda antara teks yang satu dengan teks yang lainnya. Unsur-unsur budaya itu tercermn dalam struktur teks yang dimiliki oleh masing-masing teks itu sendiri. Pemahaman akan kelokalan dalam suatu teks adalah relasi antara acuan serta konteks yang dijelaskannya. Dalam konteks ini, kelokalan dipahami dan ditafsirkan, baik sebagai produk maupun nilai yang dikandungnya bersifat humanistis yang tampak dalam teks. Berdasarkan kajian unsur budaya lokal dalam berbagai teks dan kaitanya dengan tujuh unsur kebudayaan, teks yang mengandung unsur budaya lokal tampak dalam sistem pengetahuan, sistem kemasyarakatan dan organisasi sosial, dan sistem peralatan hidup dan teknologi. 


\section{Referensi}

[1] S. Thongchalerm and W. Jarunthawatchai, "The impact of genre based instruction on EFL learners' writing development," Int. J. Instr., vol. 13, no. 1, pp. 1-16, 2020, doi: 10.29333/iji.2020.1311a.

[2] I. da Cunha and M. A. Montané, "Textual genres and writing difficulties in specialized domains," Rev. Signos, vol. 52, no. 99, pp. 4-30, 2019, doi: 10.4067/S0718-09342019000100004.

[3] C. Hermansson, B. Jonsson, M. Levlin, A. Lindhé, B. Lundgren, and A. Norlund Shaswar, "The (non)effect of Joint Construction in a genre-based approach to teaching writing," J. Educ. Res., vol. 112, no. 4, pp. 483-494, 2019, doi: 10.1080/00220671.2018.1563038.

[4] M. N. Melissourgou and K. T. Frantzi, "Genre Identification Based on SFL Principles: The Representation of Text Types and Genres in English Language Teaching Material," Corpus Pragmat., vol. 1, no. 4, pp. 373-392, 2017, doi: 10.1007/s41701-017-0013-z.

[5] R. Purba, "Using Genre-based Approach to Overcome Students' Difficulties in Writing," vol. 7, no. 4, pp. 464-470, 2020, doi: 10.20448/journal.509.2020.74.464.470.

[6] T. Barker and Y. B. Lee, "Published online: 25 September 2017 To cite this article: Barker, T. and Y. B. Lee. 2017. Making creative industries policy: The Malaysian case.," vol. 35, no. 2, pp. 21-37, 2017.

\section{Referensi lain:}

Suhendra,dkk. (2016). Nilai-Nilai social Budaya Lokal dalam Teks Tulisan Mahasiswa Program Studi Pendidikan Bahasa dan Sastra Indonesia FKIP Universitas Pakuan. Bogor: FKIP Unpak.

Depdikbud. (1994). Nilai-nilai Budaya Susastra Jawa. 1994.

Emilia, Emi. (2012). Pendekatan Genre Based dalam Pengajaran Bahasa Inggris: Petunjuk untuk Guru. Bandung.

Kemendikbud. (2014) Bahasa Indonesia. Jakarta.

Koentjaraningrat. (2009). Pengantar Ilmu Antropologi. Jakarta: Rineka Cipta.

Mahsum. (2014). Pembelajaran Berbasis Teks. Jakarta.

Moleong, Lexy J. (2013). Metodologi Penelitian Kualitatif. Bandung: Remaja Rosda Karya. 2

Resmini, Novi dan Dadan Juanda. (2008). Pendidikan Bahasa dan Sastra Indonesia di kelas Tinggi. Bandung: UPI Press.

Suparlan, Parsudi.(1984). Manusia, Kebudayaan, dan Lingkungannya. Jakarta: CV Rajawali

Wiratno. (2014). Jenis-Jenis Teks. Jakarta. Badan Bahasa 
AKSARA: Jurnal Ilmu Pendidikan Nonformal

P-ISSN 2407-8018 E-ISSN 2721-7310 DOI prefix $\underline{10.37905}$

Volume 08, (1), January 2022

http://ejurnal.pps.ung.ac.id/index.php/Aksara 